Historic, Archive Document

Do not assume content reflects current scientific knowledge, policies, or practices. 



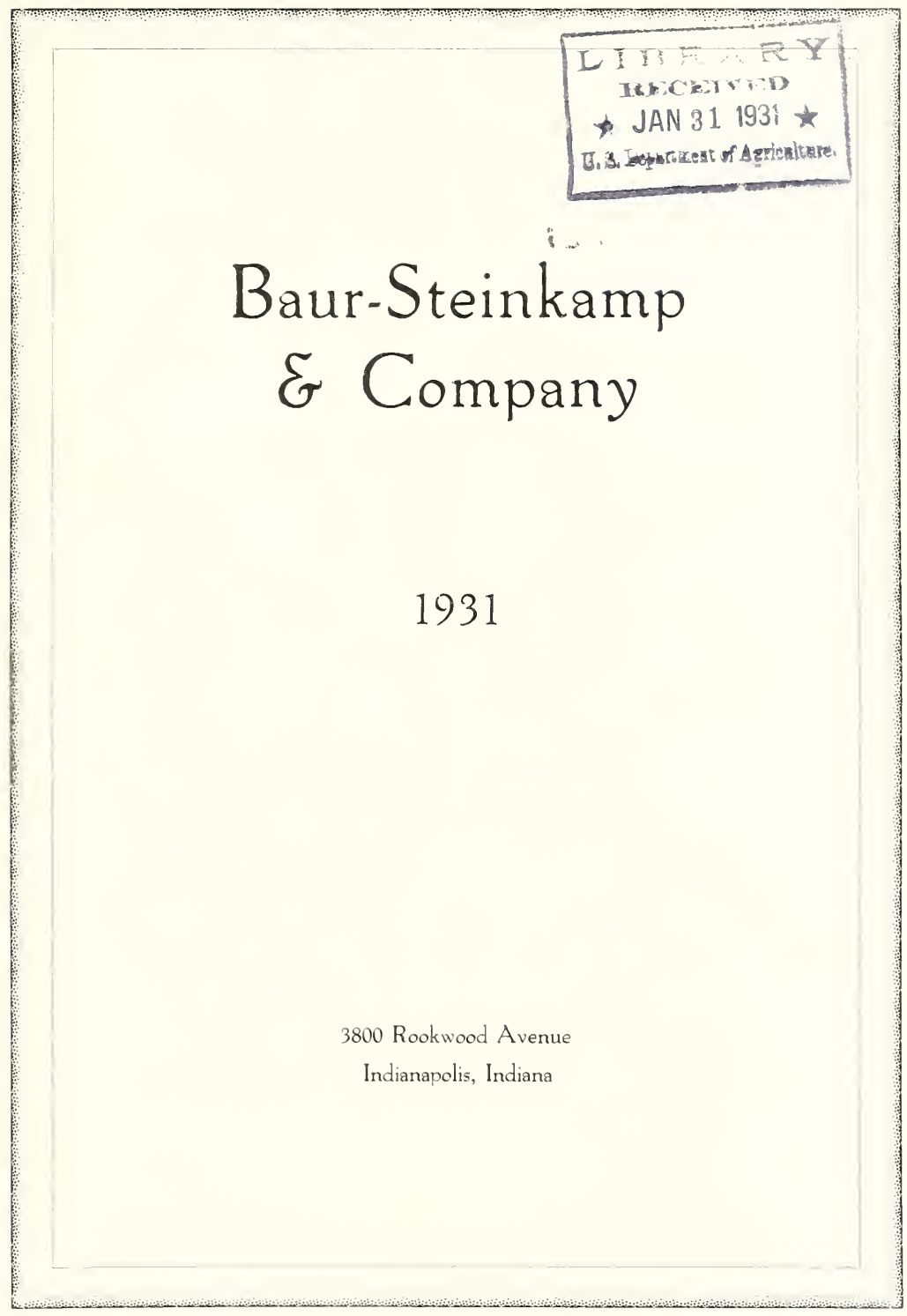




\section{《«1931»»}

OR greetings to you, and a sincere good wish for a prosperous season. The year 1931 dawns with a good prospect for the grower who holds steadfast to good business principles and progressive methods. In these times of stress it is more essential than ever to stock the very best varieties and practice up-to-date cultural methods. The new varieties listed in this catalogue are offered in the belief that each one is superior in its particular class. Our disseminations of past years are our best guarantee of the merits of our 1931 offerings. We invite you to visit us and inspect our stock.

Prices quoted in this catalogue are for rooted cuttings unless otherwise noted. We sell 25 at hundred rates, 250 at thousand rates. Orders are accepted subject to availability of stock and filled in rotation as received, unless later delivery is requested.

All bills are due on the first day of the month following shipment. Patrons ordering from us for the first time, will please send references.

We will exercise our best judgment as to the best means of forwarding, unless shipping instructions are given. In case of damage in transit, file claim with the transportation company, and advise us of your action. We will lend every assistance in establishing your claim.

Baur-Steinkamp \& Co. 


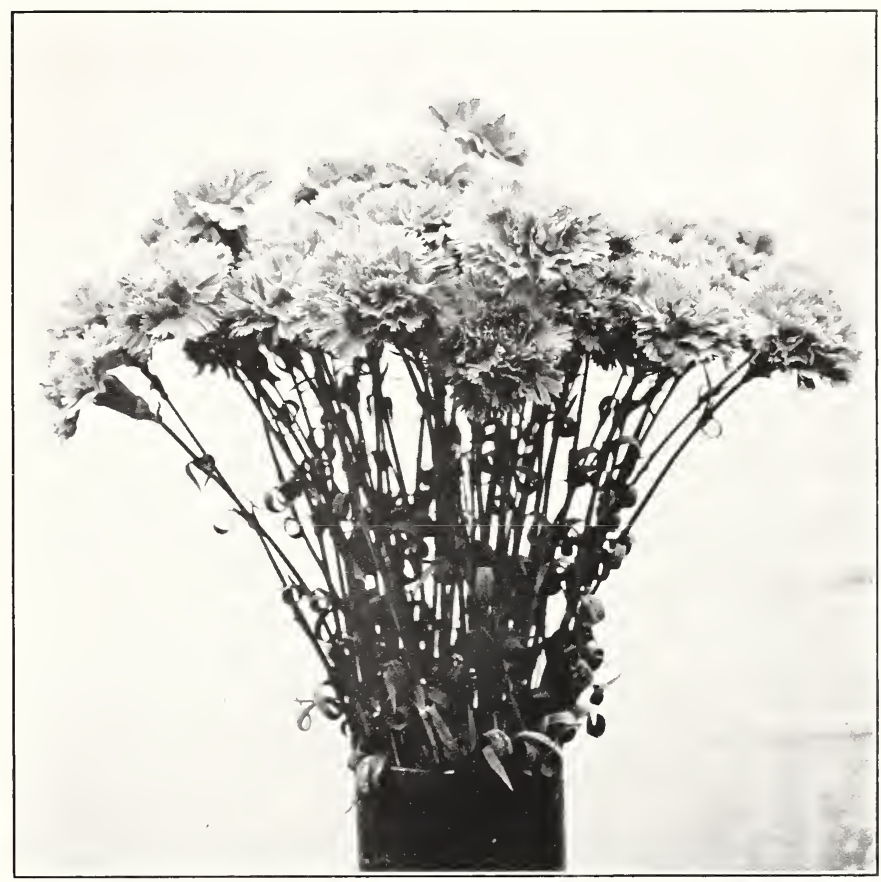

\section{"ILLUMINATOR"}

In Illuminator we offer you a carnation which we feel sure will be rated a bread and butter variety. Its bright cerise pink color at once attracts attention, and it holds its brightness unusually long, turning to a pleasing medium pink as the bloom ages. The size, calyx and stem are all good and it "puts out the blooms."

Illuminator won the A. C. S. bronze medal in the fall of 1929, and again in 1930. Scored 92 points by the State Florists Association of Indiana in January, 1930. Scored 93 points by the Chicago Florists Club in February, 1930. Won first premium in the 100 dark pink class at the A. C. S. meeting in Detroit last January. Won the National Flower Show bronze medal at Minneapolis last March.

We have tested this variety since 1925 and have worked up a large stock to propagate from. You will like Illuminator.

$\$ 3.00$ per Dozen, $\$ 15.00$ per $100, \$ 125.00$ per 1000 


\section{Rooted Cuttings}

In our endeavor to supply our patrons with the very best quality cuttings, we are growing many thousands of plants for cutting production only. These were kept cut back, thus throwing the plant's entire strength into the cuttings. Our propagating beds are now filled with these plump cuttings.

\section{Our 1930 Introductions "SPICY WHITE"}

As a producer of high grade, pure white blooms, Spicy White has few equals among the standard varieties. It comes into bloom quickly after being benched, and continues right through the season. It has displaced Harvester on our blooming benches.

$\$ 12.00$ per $100 ; \$ 100.00$ per 1000

\section{"SALMON SPECTRUM"}

This variety bids fair to displace all other flesh or salmon colored sorts. Being a sport from Spectrum insures its productiveness and keeping quality. Should be a wonderful shipper. W'e have a fine stock for propagating.

$\$ 10.00$ per $100 ; \$ 90.00$ per 1000

\section{"POTENTATE"}

Its fine velvety purple color adds a richness wherever it is used, which is appreciated by the floral artist. Ideal in size, calyx and stem, and very free in bloom production. We were unable to fully supply the demand last season.

$\$ 12.00$ per $100 ; \$ 100.00$ per 1000

\section{The Standard Sorts}

\section{"HARVESTER"}

\section{B. S. \& Co. 1922}

Harvester is still grown by many in preference to all other standard white varieties. Its great freedom makes it highly profitable. Always pure white.

$\$ 5.00$ per $100, \$ 45.00$ per 1000

\section{"SENATOR"}

Produces fine pure white blooms on long stems. Makes a fine appearance on the bench and has made many friends since its introduction in 1929.

$$
\$ 6.00 \text { per } 100, \$ 50.00 \text { per } 1000
$$

\section{"EARLY ROSE"}

We rate this among our best paying varieties. Very free flowering and a good seller. Should be permitted to develop well on the plant before cutting. Beautiful satin rose. Makes fine plant in the field.

$$
\$ 5.00 \text { per } 100, \$ 15.00 \text { per } 1000
$$




\section{"PINK ABUNDANCE"}

B. S. \& Co. 1929

This splendid variety is displacing all other medium pink sorts on many places. Its wonderful production of bloom and its easy management appeal to the grower. The stem is always long and strong, and the color is always clear medium pink of Betty Lou shade. No splits and no culls. Makes fine plants in the field and reestablishes itself quickly after being benched. We have a large stock for propagating and can supply Pink Abundance in almost unlimited quantity.

$\$ 6.00$ per $100, \$ 50.00$ per 1000

\section{"DEL RAY"}

A nice looking medium pink which came to us from the east. Medium sized blooms with good color. In its first year out it bids fair to make good.

$$
\$ 12.00 \text { per } 100 ; \$ 100.00 \text { per } 1000
$$

\section{"RADIOLITE"}

\section{B. S. \& Co. 1927}

Our main reliance for high grade scarlet blooms. Needs a little extra attention in building up the plant for an early crop, but responds readily to good care and blooms steadily throughout the season. Wonderful color and no culls.

$\$ 6.00$ per $100, \$ 50.00$ per 1000

\section{"SPECTRUM"}

Most extensively grown scarlet on account of its extreme freedom. Wonderful keeper and shipper. Roots very easy and makes fine plant in the field. We have a large stock for propagating.

$$
\$ 5.00 \text { per } 100, \$ 45.00 \text { per } 1000
$$

\section{"ELDORA"}

Has become the standard white variegated. Blooms profusely during the winter months. Medium pink on pure whitte ground.

$$
\$ 6.00 \text { per } 100, \$ 50.00 \text { per } 1000
$$

\section{"VARIEGATED-MATCHLESS"}

Bright coral flake on white background. Being a sport from Matchless insures its fine keeping qualities. Appreciated by those who are wont to depart from the conventional self colors. Shows up fine in spray and basket arrangements.

$$
\$ 6.00 \text { per } 100, \$ 50.00 \text { per } 1000
$$

\section{"EARLY DAWN"}

Yellow striped pink. Works up wonderful and blends with all other varieties. The artist's delight. $\$ 12.00$ per $100 ; \$ 100.00$ per 1000

\section{"WOBURN"}

The best crimson today. A wonderful flower on a perfect stem. Bright crimson with enough scarlet in the color to make it loom up.

$$
\$ 12.00 \text { per } 100 ; \$ 100.00 \text { per } 1000
$$

\section{"LADDIE"}

Still the aristocrat among the carnation family. Not so free as some, but wonderful in quality. Needs extra attention to get free flower production, so it must, and does, bring the top price.

$$
\$ 12.00 \text { per } 100 ; \$ 100.00 \text { per } 1000
$$




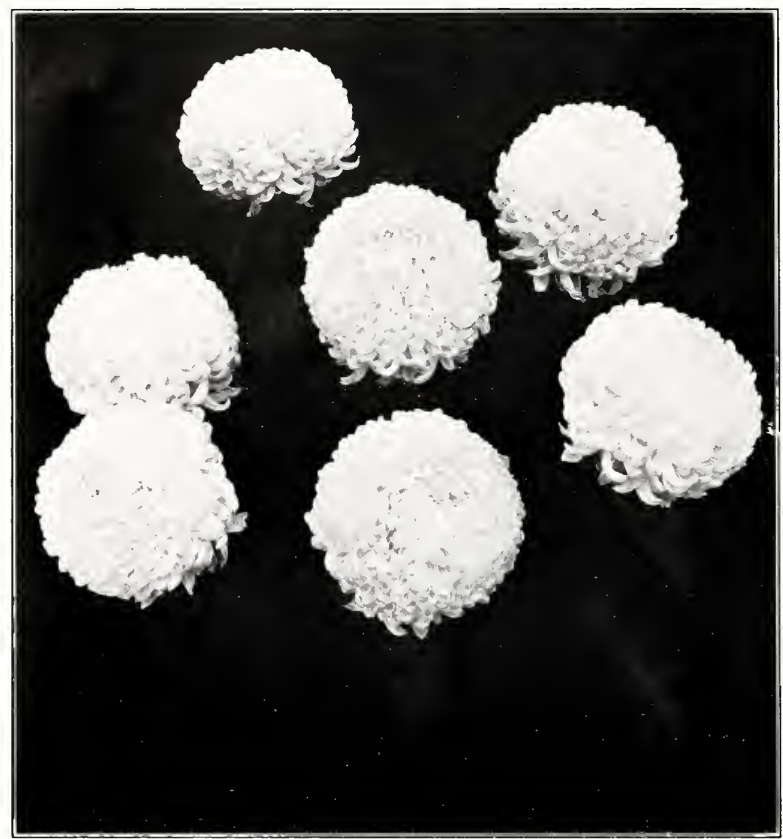

"AMBASSADOR"

This variety should prove valuable, especially, to those growers who ship into the large markets and need extra size, early, to protect their markets. Producing blooms as large as Turner by the middle of October, gives this variety an extra value. Its blooming date is October 16th to 20 th from terminal bud. The stem is strong and holds the bloom up perfectly without artificial support. It is pure white in color and grows five feet from June planting. Needs no special culture to perfect its handsome blooms.

$\$ 5.00$ per Dozen, $\$ 25.00$ per $100, \$ 200.00$ per 1000 


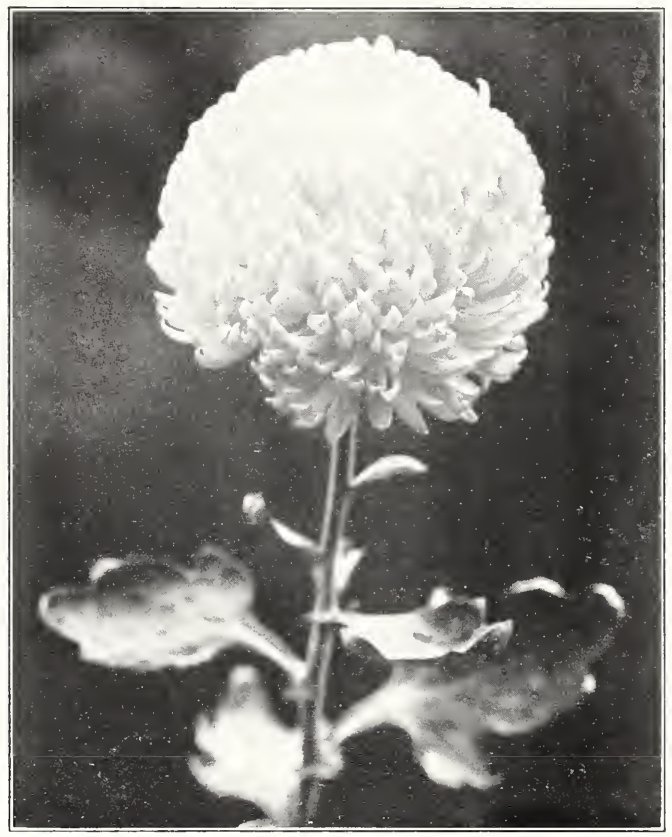

\section{"YELLOW GOLD"}

Yellow Gold is one of those globular incurved varieties that are the shipper's delight, and of which it is well nigh impossible to have too many. The color is a clear bright yellow. The foliage is medium in size, permitting fairly close planting. Grows five feet from June planting and blooms November 1st to 15th from terminal bud. Awarded bronze medal Louisville show November 13 th and a certificate of merit at the National Mum show at Detroit.

$$
\$ 5.00 \text { per Dozen, } \$ 25.00 \text { per } 100, \$ 200.00 \text { per } 1000
$$




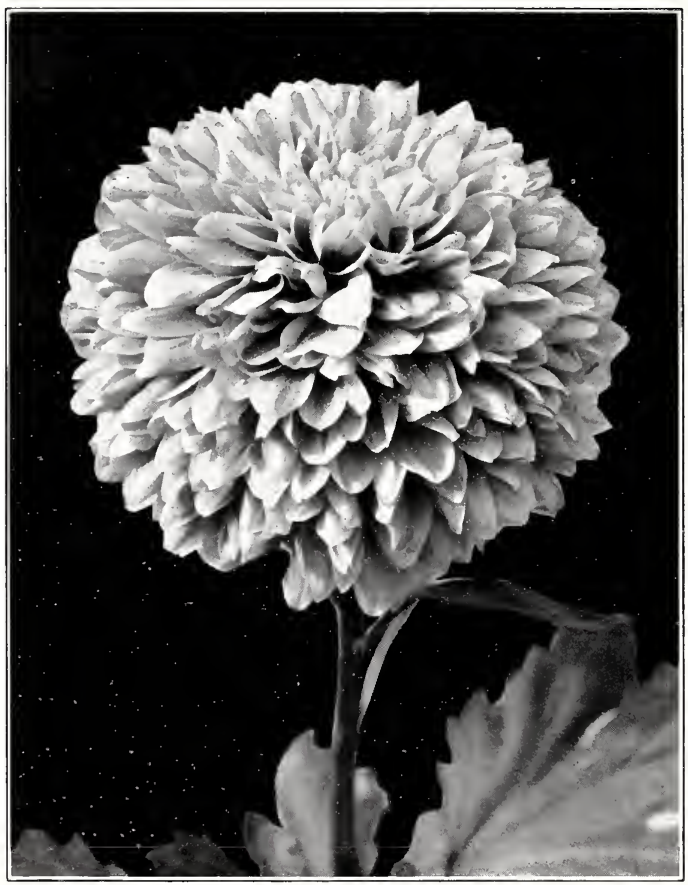

\section{"OLD ROSE"}

A most pleasing shade of old rose and a splendid seller in our market. The bloom has unusual substance. Can be bloomed from either late crown or terminal bud, the crown bud flower coming a few days earlier and somewhat larger. Good stem and foliage. Grows five feet from June planting. Blooms early in November. Awarded silver medal at Louisville show November 13 th.

$\$ 5.00$ per Dozen, $\$ 25.00$ per $100, \$ 200.00$ per 1000 


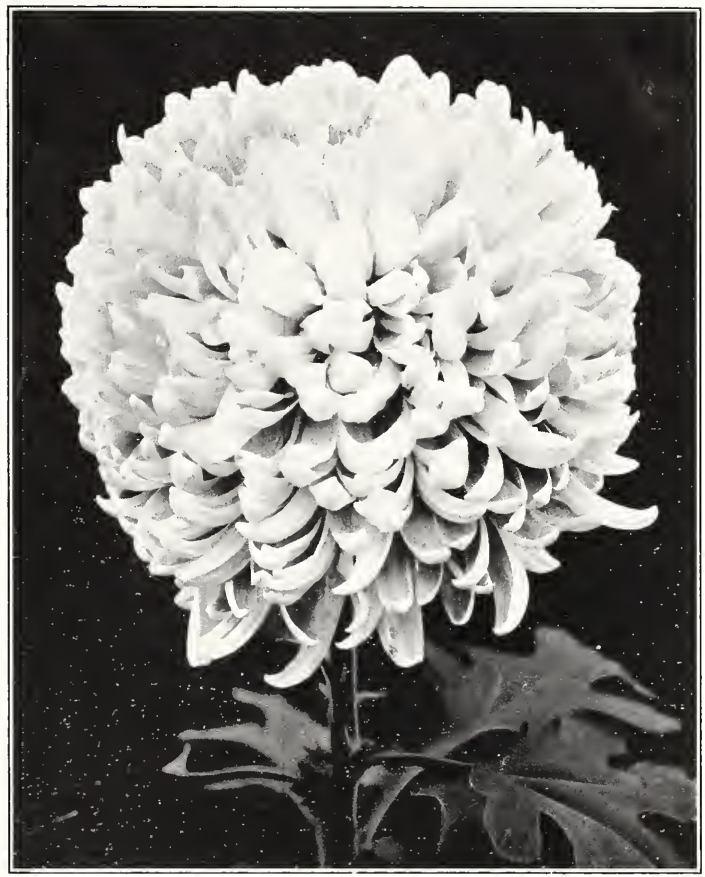

\section{"WHITE DISTINCTION"}

This is a pure white sport from Distinction. Those who grow Distinction as a late midseason pink, will appreciate this pure white sport. It has the same splendid substance and the same fine upright habit. It grows four feet from June planting and blooms November 15th. Take terminal bud.

$\$ 5.00$ per Dozen, $\$ 25.00$ per $100, \$ 200.00$ per 1000 


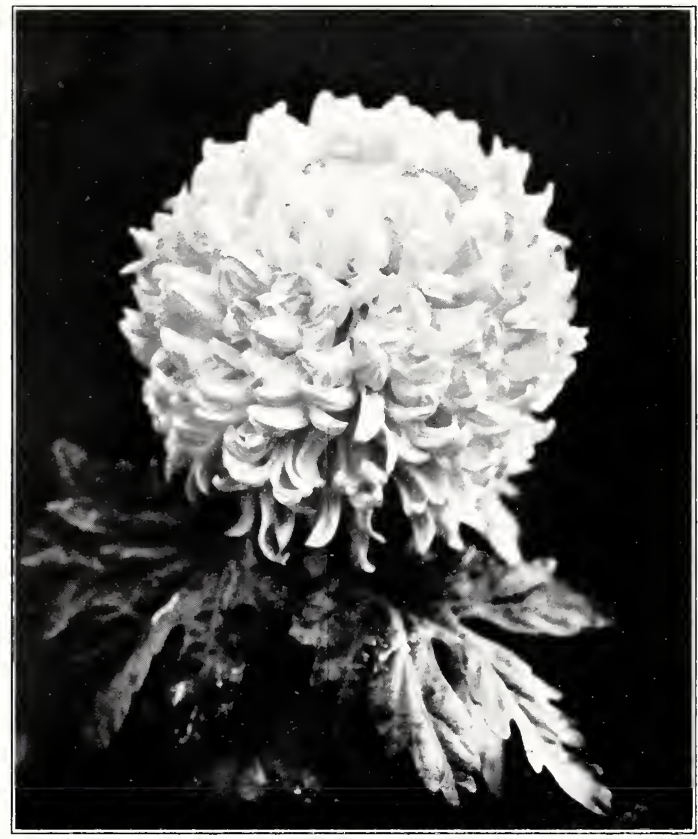

"GOLDEN PEARSON"

A clear bright yellow sport from the popular bronze variety Gladys Pearson. Sported with us some three years ago and has shown no inclination to revert. Like its parent, it comes just right for Thanksgiving Day and should be planted heavily for that day. We have a large stock to propagate from, therefore the price.

$\$ 12.00$ per $100, \$ 100.00$ per 1000 


\section{"LEGAL TENDER"}

We consider this one of the very best pompons we have ever raised. The color is a wonderful combination of bronze and gold, which attacts the eye among a houseful. Belongs to the large flowered pompon type and produces handsome sprays. The plant bushes readily and quickly fills the benchspace. Should make a splendid variety for pots. Blooms November 20th and later. Fine for Thanksgiving. \$5.00 per Dozen, \$25.00 per 100, \$200.00 per 1000 .

\section{"AMOS"}

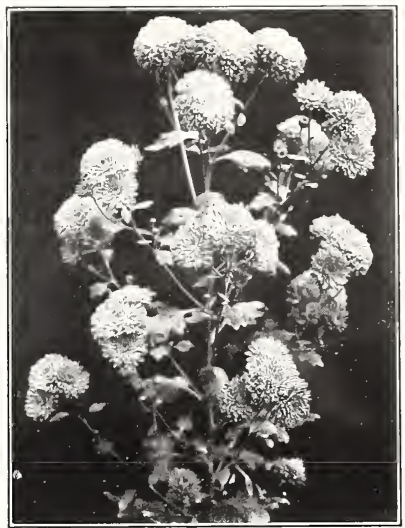

"LEGAL TENDER"

A good medium shade of bronze without other shading. Holds its color fine. Medium sized blooms, produced in fine open sprays, each bloom standing out to itself. Fine for cutting, giving a good yield. Blooms November 10th.

$\$ 5.00$ per Dozen, $\$ 25.00$ per $100, \$ 200.00$ per 1000

\section{"JEWELL"}

One of the best varieties for outdoor planting as well as a splendid sort for indoor cutting. The blooms are of the large button type, like Nuggets. The color is a pleasing shade of bright clear pink, which is still more wonderful outdoors. Comes into bloom October 15th inside, but outdoors it shows its fine color in the bud and half open bloom about October 1st and makes a brilliant showing for several weeks.

$\$ 5.00$ per Dozen, $\$ 25.00$ per $100, \$ 200.00$ per 1000

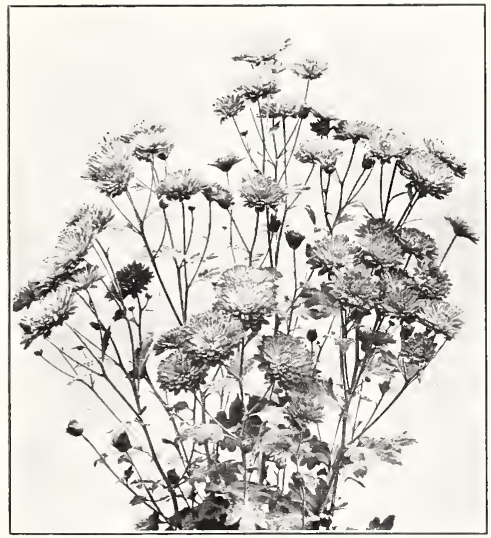

"AMOS"

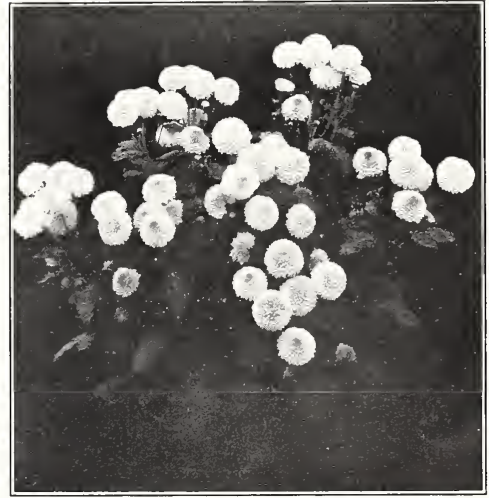

"JEWELL" 


\title{
STANDARD VARIETIES
}

\author{
$\$ 4.00$ per $100 ; \$ 35.00$ per 1000 , except where noted
}

\section{WHITE}

QUAKER MAID - B. S. \& Co. 1927. Planted early in June and bud taken August 25 th, this variety will come into flower the first week in October. Has become the standard early white.

WHITE CHIEF-B. S. \& Co. 1930. Plant this variety to follow Quaker Maid. Round, pure white bloom, carried on rigid straight stem. Foliage medium size and set close on the stem. Can be planted fairly close. Take terminal bud. October 15th. $\$ 12.00$ per $100 ; \$ 100.00$ per 1,000 .

SNOW-WHITE-B. S. \& Co. 1924. Purest white of any mum we know. Good sized bloom on fine stem and foliage. One of our very best whites. Blooms October 25th. Take terminal bud.

MONUMENT-B. S. \& Co. 1924. A great favorite among the growers who ship their blooms to market. Large incurved blooms of great substance, born on strong stems. Foliage medium size. Blooms November 10th. Take terminal bud. $\$ 6.00$ per $100 ; \$ 50.00$ per 1000 .

MEFO-Large incurved bloom with milky white color. Beautiful foliage on fine stem. Must be permitted to develop fully before cutting. November 15 th from terminal bud.

MARGARET GRAHAM-B. S. \& Co. 1929. One of the most beautiful mums we know of. Pure white bloom of good size, with broad waxy petals and born on fine stem with ample foliage. We can imagine nothing more beautiful than a bench of Margaret Graham. Blooms November 15th to 20th. Take terminal bud.

FAVORITE-An English variety that has caught on over here. Milky white in color. Good stem and foliage. Blooms November 10th, take terminal bud.

TOWANTIC - Plant late in June or early July and take terminal bud for best results. Pure white in color and large in size. Blooms Thanksgiving day and later.

\section{YELLOW}

GOLD LODE-B. S. \& Co. 1927. Our earliest large flowered yellow, coming into bloom October 1st. Plant early in June and take bud August 25th. Handsome foliage and good stem. Fine for pot culture.

CELESTRA - B. S. \& Co. 1929. Plant Celestra to follow Gold Lode, coming into flower October 15th. Globular in form, making it a fine shipper. This is one of those varieties that can be grown into any size without losing its shape, and sold in unlimited quantity. Will become as popular as Gold Lode. Take terminal bud. $\$ 6.00$ per $100 ; \$ 50.00$ per 1000 . 
GOLDEN GLORY - B. S. \& Co. 1922 Best yellow for last week in October. Fine golden yellow of large size and borne on fine stem. Also a good pot plant variety. Take terminal bud.

HONEYDEW - Clear lemon yellow. Iarge incurved bloom on fine stem, clothed with beautiful foliage. Grow fairly strong and take terminal bud for best color. Bloon November 10th.

FRIENDLY RIVAL--Its wonderful deep yellow color has made this variety a great favorite. Was planted in large quantity this past season and has made good. We have a good stock. Take terminal bud to bloom November 10 th to 20 th.

MARIE de PETRIS - Made many friends since its debut in 1929, by its sturdy growth and fine form. Clear golden yellow incurved. Stock is still limited and in great demand. Blooms November 10 th to 20th. Take terminal bud. $\$ 12.00$ per $100 ; \$ 100.00$ per 1000 .

GOLDEN CELEBRATION-B. S. \& C.o. 1928. Rapidly displacing Celebration as the great Thanksgiving yellow. Our bed was a wonderful sight this year on November 20th. Ideal upright growth. Good substance and a fine shipper. Plant any time in June and take terminal bud. We carry a very large stock. $\$ 6.00$ per $100 ; \$ 50.00$ per 1000 .

SUNBEAM - Clear Bonnaffon yellow. Globular form and good size. Comes into bloom just right for Thanksgiving. Take terminal bud.

MRS. R. M. CALKINS - Large spreading flower on strong stem. Deep yellow in color. Comes best from late crown bud. November 25th.

MRS. NELLIE T. ROSS--Large, handsome, Bonnaffon colored bloom, carried on strong stem. Good foliage. Comes into bloom naturally for Thanksgiving. One of our standbys for late flowering. Take terminal bud.

\section{PINK}

LUSTRE-B. S. \& Co. 1928. Plant early in June and take last crown bud, late in August, which will bring it into flower early in October. Clear lavender rose. Enjoys a light shade while coming into flower. Terminal bud blooms October 10 th.

ROSE GLORY - B. S. \& Co. 1930. Plant this to follow Lustre. Large incurved flower with good substance. Strong upright growth with fine foliage. A real acquisition to the early pinks. Take terminal bud. Blooms October 15th. $\$ 12.00$ per $100 ; \$ 100.00$ per 1000 .

JUSTRITE-B. S. \& Co. 1929. This is another of those incurved commercial varieties of which one can hardly grow too many. Grow one or more blooms to the plant according to what sized bloom is desired. Always good. Clear satin pink. Take terminal bud. Blooms October 15 th. $\$ 6.00$ per $100 ; \$ 50.00$ per 1000 .

OCTOBER ROSE- B. S. \& Co. 1925. Grown in large quantity to flower October 20th. Large in size. Good stem and foliage. Clear lavender rose. Take terminal bud. 
GLORIOUS - B. S. \& Co. 1921. Needs to be planted early in June to do its best. Fine clear pink, coming into flower the first week in November. Take terminal bud.

PINK TREASURE-Much larger and finer bloom than Chieftain and should be planted in its place. Clear rose pink. Take terminal bud and shade lightly while the bloom is developing. November 10.

DISTINCTION - B. S. \& Co. 1925. Our very best commercial pink for November 15-25. Can be held for Thanksgiving if grown cool. We count on every bloom being good. Straight and strong stem. Take terminal bud.

THANKSGIVING PINK - B. S. \& Co. 1921. Most dependable pink for Thanksgiving day. Plant early in June and take terminal bud. Also a wonderful pot variety.

INDIANOLA - B. S. \& Co. 1928. Plant this varicty early in June and take last crown bud about September 1st, to get it into flower early in October. Has jumped right into favor on account of its earliness and wonderful color. $\$ 6.00$ per $100 ; \$ 50.00$ per 1000 .

GOLDEN BRONZE-B. S. \& Co. 1930. Can be grown to one or more blooms per plant with good success. Always produces perfect blooms on good stems. One of our favorites. Wonderful golden bronze. Blooms October 15th. Best color from terminal bud. $\$ 12.00$ per $100 ; \$ 100.00$ per 1000 .

GLADYS PEARSON-Best bronze for late November cutting, lasting over Thanksgiving. Grown in large quantity. Large incurved bloom with fine substance. Take terminal bud for best color.

\section{POMPONS}

$\$ 4.00$ per $100 ; \$ 35.00$ per 1000 , except where noted.

AUTUMN GLINTS - B. S. \& Co. 1922. Golden yellow with crimson reverse, gives a bronze effect while opening. November 1st.

BUCKINGHAM-Fine single pink. Produces fine large sprays. November 1st.

BOKHARA-B. S. \& Co. 1925. Beautiful autumn shades. October 15th.

DOROTHY TURNER - Late flowering bronze. November 20th.

FLORA-Best deep red. November 10th.

FRANK W'ILCOX - The great Thanksgiving day bronze.

GOLDEN CREST - Late bright yellow. November 25th.

GOLD DROP - B. S. \& Co. 1928. Golden bronze with crimson eye. November 1 st.

GOLD TIPS - B. S. \& Co. 1930. A fine novelty in bronze and gold. November 20. IRIDESCENT - B. S. \& Co. 1930. Various shades of gold and pink. October 15th.

IDA Good early yellow. October 15 th. 
LILAC-B. S. \& Co. Best early pink. October 15 th.

LEILAH-Good early pink. October 15th.

LUCINDA-B. S. \& Co. Bright pink. November 10th.

MRS. KLERIS - Good midseason pink. November 1 st.

NORINE--Large button type, golden yellow. One of the best for late cutting.

NUGGETS - B. S. \& Co. 1924. Best large button type yellow for early November. Fine for pot culture. November 1st.

NUBIAN-B. S. \& Co. 1928. Early bright chestnut bronze. October 15th.

PINK DOT-B. S. \& Co. 1924. White with crimson eye. October 25th.

ROSE CHARM-B. S. \& Co. 1924. Bright rose. Fine for disbudding as well as for sprays. November $1-5$.

ROWENA-Tall growing bronze for late cutting. November 25th.

RiD BEU-Bronze and gold for Thanksgiving.

SARAH TOWNSEND - Bright golden bronze. November 15th.

SILVER TIPS - B. S. \& Co. 1930. A wonderful bright pink for mid-November.

SUNBURST - B. S. \& Co. 1929. Bronze and gold, giving sunburst effect. Very fine. November 10 th.

VARSITY - Button type yellow. Fine for pots. Late October.

WHITE CAPS - B. S. \& Co. 1925. Pure white. November 1st.

WHITE DOTY - White sport from Lilian Doty. November 1st.

WHITE WINGS - Fine early white. October 15 th. $\$ 6.00$ per $100 ; \$ 50.00$ per 1000 .

YELLOW DOTY - Not a sport from Doty, but same typc. Bright yellow. November 1st.

YELLOW FELLOW-B. S. \& Co. 1925. Deep clear yellow. One of our very best for mid-November cutting.

YULETIDE-Pure white for late cutting. December 1 st and later.

GARZA SUPREME--Single. Like Garza, but blooms in December.

\section{SPECIAL CHRYSANTHEMUM OFFER}

You may select a thousand rooted cuttings or more, from the list of standard varieties, excluding Monument and Marie de Petris, at $\$ 35.00$ per 1000 , providing the number ordered of any one variety does not amount to more than $10^{\prime}$; of the entire order. We will be glad to make up an assortment to cover the season in the various colors, taken from the list of standard varieties at $\$ 30.00$ per 1000 , to include not more than 100 nor less than 25 of any one variety in each thousand cuttings. 


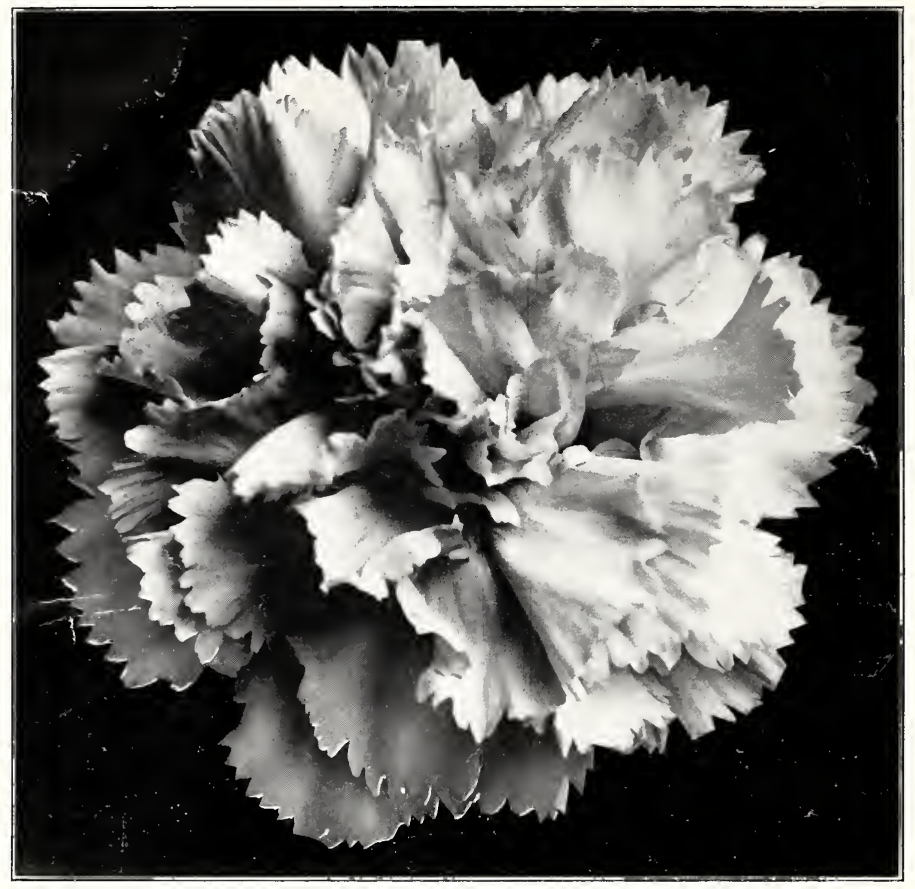

\section{"SALMON SPECTRUM"}

Comparing the several salmon colored sports from Spectrum, we find that the one we introduced last season under the above name is clearer in color and less inclined to split the calyx. It blooms as freely as Spectrum and has the same keeping quality, therefore it is highly profitable and a good shipper. We have a large stock to propagate from. 